\title{
After Cannibal Tours: Cargoism and \\ Marginality in a Post-touristic \\ Sepik River Society
}

Eric K Silverman

\section{"Long Wanem You Laik Kisim Dispela Moni?"}

Toward the end of the celebrated film Cannibal Tours (O'Rourke I988), the filmmaker, speaking with an older man from the Sepik River in Papua New Guinea, asks, "Why do you allow the tourists to come here?" The answer cuts to the chase: "Because we get money." Tourists pay to photograph the local men's house, and they buy wood carvings. It's all about the money.

The filmmaker next poses a rather more loaded question: "Why do you want this money?" His Sepik interlocutor seems slightly annoyed, as if he finds the query silly. Still, he complies. "To purchase," he says in tokpisin (the lingua franca of polyglot Papua New Guinea), "trousers, laplap waistcloth, and wanem samting"-that is, whatever. He repeatedly uses the tokpisin pronoun mi. The tourists must help $m i$ with money. They must compensate $m i$ for the labor of constructing the men's house. And "Mi wokim carvings"- that is, "I" made the artifacts. Linguistically, these utterances seem to underscore the relationship between individualism, tourism, and modern longing. It's all about money and $m i$.

A Sepik men's house represents social order, gender, ancestral prominence, and cosmogony. Hence, payment by tourists is locally seen as an acknowledgment that Sepik cultures hold enduring value and relevance in the world today. These fees also serve as "weapons of the weak" that symbolically resist an unequal global encompassment (Scott I 985 ; see also Gewertz and Errington I99I, 7I). All told, money in the Sepik is a means to a practical end - to buy wanem samting — and a symbol of personhood,

The Contemporary Pacific, Volume 25, Number 2, 22 I-257

(C) 2013 by University of Hawai'i Press 
desire, self-worth, cultural prominence, and defiance. Yes, it's all about the money-but money here is both instrumental and representational (see also Foster 2002, 36-60; Akin and Robbins I999).

I agree that Cannibal Tours forcefully portrays the violence inherent in tourism in Papua New Guinea, the wider Pacific, and the global periphery more generally. ${ }^{1}$ But the iconic status of the film rests on the elicitation of powerful emotions rather than on richly textured insights into the longings and experiences of local people. With the exception of one enraged woman, Sepik dwellers generally appear mystified, awkward, and disempowered-cutouts, really, lacking voice or agency (Silverman 2004). Cannibal Tours, then, reduces the complexity of the touristic encounter to an uncomplicated, albeit compelling, moral fable.

My goal in this article is not to offer a detailed analysis of Cannibal Tours. Instead, I use the film as a springboard for a more nuanced and sustained view of tourism in Melanesia, drawing mainly on ethnographic fieldwork in 20 Io but extending back to the late I 980 s. First, I sketch the plight of one middle Sepik River community, the Eastern Iatmul village of Tambunum, that yearns for a "road" to modernity (largely hewn through tourism) but increasingly admits to "going backwards." Second, I argue that tourism allows local people to express artistically messages about gender, identity, and sociality in the Melanesian postcolony. Last, I demonstrate what happens when the tourists go home, as they have-almost all of them. And therein lies the tragedy.

Several weeks into my first period of fieldwork in I988, I witnessed the maiden voyage of the Melanesian Discoverer, a plush catamaran cruise ship that replaced an earlier steamship, the Melanesian Explorer. (The latter is featured in Cannibal Tours.) The Melanesian Discoverer, berthed at the Madang Resort Hotel and operated by the Melanesian Tourist Travel Services, accommodated forty-two passengers in twenty-one cabins, each with a private bathroom, television, telephone, and music system. The air-conditioned ship also contained a dining room, library, cocktail bar, and helipad. The vessel represented the marvels and bounty locally associated with modernity—so close, yet so far from local grasp. (As one man fantasized in Cannibal Tours, "If tourists paid more for my carvings, then I could go on that ship.") The Melanesian Discoverer regularly plied the Sepik for many years. But the ship was recently sold, and now Tambunum village rarely receives visitors. And with no tourists, as many Eastern Iatmul said in 2010 , there is no money.

During the peak of large-scale tourism in the Sepik from the late-I980s 
through the mid-I990s, Eastern Iatmul often expressed discontent about the local level of "development." Still, they viewed tourism, especially the sale of wood carvings, as a reliable "road" (or rod in tokpisin) to money. But with the decline in tourism, which corresponds to a dramatic degradation of "basic services" as offered by the national and provincial governments, Eastern Iatmul feel increasingly disenfranchised and despondent. Indeed, villagers now speak in terms I never expected to hear in this once prosperous community: narratives about deceased kin, voyaging back to the village like ghostly tourists on a numinous ship, striving to bring local people wealth and commodities, only to be barred by Europeans. I am sympathetic to viewers of Cannibal Tours, and critics of tourism more generally, who feel uneasy with the voyeuristic exploitation of "natives." But this disquiet pales in comparison to the local experience of economic woe in the post-touristic Sepik. What happens after Cannibal Tours? The answer, sadly, is the ideology of a cargo cult that locates the riches of modernity in a ghostly afterlife selfishly made inaccessible to Melanesians by deceitful, rapacious Europeans in collusion with Asians.

There are many losses, both real and interpretive, in Melanesia today and in the wider Pacific arising from the encounter with modernity, including shuttered mines, environmental degradation, deforestation, rising coastal waters, and a general sense of subaltern passivity amid attenuating governmental services (eg, Knauft 2002; Kirsch 2006; Halvaksz 2008; Lipset 20II). Like many peoples in the Pacific and elsewhere at the global fringe, Eastern Iatmul feel an increasing sense of detachment from what James Ferguson, writing about the Zambian Copperbelt, termed the "grid of modernity" (2002, I40). And like the Copperbelt miners studied by Ferguson, Eastern Iatmul also experience a sense of abjection-that they are not simply excluded from modernity but tossed aside, thrown out, hurled back, or as Ferguson continued, "cast outward and downward into the world of rags and huts" (2002, I40).

But for all that they have in common with other marginalized peoples, Eastern Iatmul are noteworthy on account of the prominence of Cannibal Tours in the classroom and in scholarly discourse. Through no agency of their own, they were made famous as a symbol of global inequality. The Eastern Iatmul are also remarkable for their dramatic decline in both ethos and material well-being. For their premodern regional hegemony, Deborah Gewertz rightly dubbed the Iatmul the "princes of the Sepik" (I983, I 24). Today, these very same princes now feel like forgotten, Dickensian paupers begging at the feet of globalization. 


\section{“GOING BACKWARDS"}

Let me return to the question, "Why do you want money?" This seemingly sensible inquiry oddly implies that money is a novelty or some frivolous accessory to everyday life in the Sepik. The people of Tambunum would find the question absurd. For them, social life today pivots on the lack of money, not the presence of desire. They voice need to pay for all sorts of necessities: petrol, outboard motors, kerosene, flashlights, radios, batteries, clothing, medicine, soap, laundry detergent, school fees, shoes, food, fishing nets, tobacco, cooking utensils, building supplies, pens, notebooks, wood-carving chisels, basketry dyes, and so forth. Money also pays for transportation to and from Wewak, the capital town of the East Sepik Province. Why do Melanesians want money? Because they inhabit a thoroughly postcolonial and globalized world, not some primitivist fantasy. And, to a large extent, Eastern Iatmul see tourism as a prerequisite to their participation in that modern world.

The Melanesian Explorer visited Tambunum several times a month. Eastern Iatmul collectively earned a sizable revenue from the sale of art and other souvenirs, especially in comparison to nearby communities that received few or no tourists. Tourism was the largest source of cash in the village and thus fueled ongoing, if low-level, monetary transactions for betel nut, tobacco, petrol, and a variety of foods and products available in local tradestores (figure I). These small-scale enterprises require complex negotiations of profit, savings, borrowing, credit, and record keeping (Curry I999, 2005). Many tradestore goods in the late I980s were imported: Nescafé instant coffee, Japanese-packed tins of mackerel, National Hi-Top batteries (Panasonic), Oki cooking oil (Singapore), Disprin pain reliever, Gillette razor blades, Carnation instant milk, curry powder, Omo and Sudso laundry detergents, and so forth. Other items were produced in Papua New Guinea, such as Tulip pork luncheon meat, Ox and Palm corned beef, matches, pouches of Spear tobacco, and Ramu sugar (figure 2). Tradestores tangibly tied the village to wider national and transnational commodity flows. Tradestores also evidenced that capitalism was as prominent as reciprocity. Indeed, the two spheres of exchange were highly interwoven. Many Eastern Iatmul maintained savings accounts in Wewak at Westpac Bank or the Papua New Guinea Banking Corporation. The local cash economy was, if not exactly thriving, at least in full swing.

During the late I980s, in fact, tourism transformed Tambunum into 


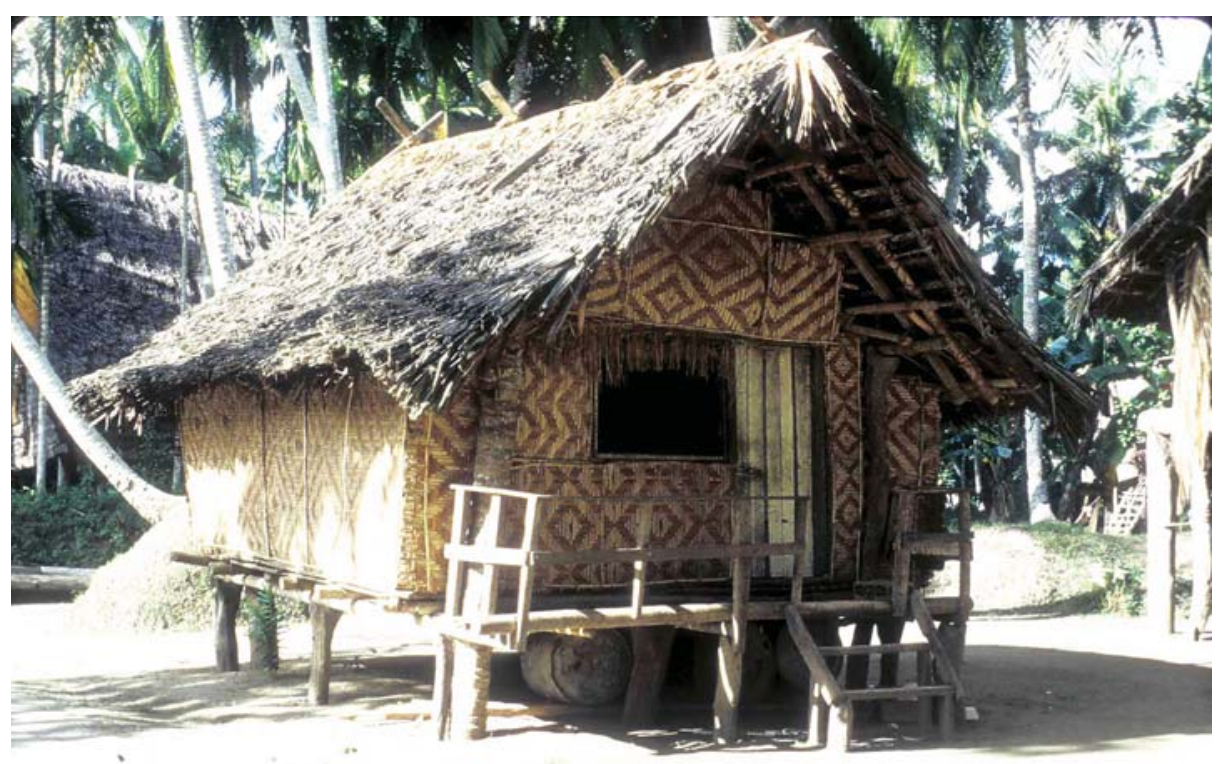

Figure I Typical village tradestore. Photo by author. (Tambunum, I989)

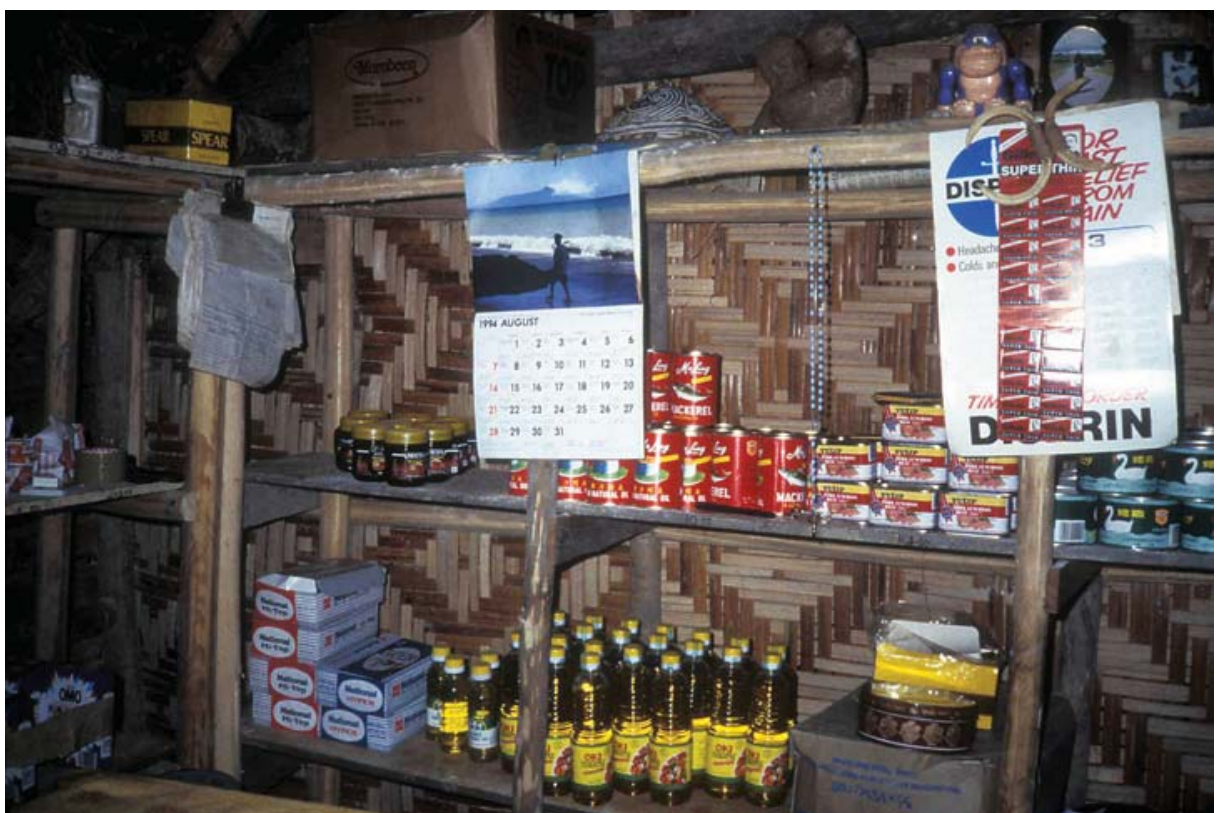

Figure 2 Typical array of tradestore goods in the late-I980s and mid-I990s.

Photo by author. (Tambunum, I994) 
perhaps the most prosperous village along the river. People from neighboring communities regularly visited by canoe to peddle tubers, smoked meat, vegetables, fruit, betel nut, sago, and pottery. Men from nearby bush-dwelling communities trekked to the village to sell their own wood carvings to tourists. Tambunum proudly viewed itself as an entrepôt that justifiably garnered regional envy and international renown. In self-perception, the community was a destination.

A little over a decade ago, however, tourism in Papua New Guinea plummeted. In 2005 , for example, official figures report $\mathrm{I} 8,000$ "holiday travellers" out of a total of 70,000 overseas visitors (ICCCPNG and PNGTPA 2006, 23). There are few reliable or official figures for earlier or recent years. Regardless, both local people and the Melanesian Travel Services perceived a dramatic decline. As a result, Melanesian Travel Services sold the Melanesian Discoverer in late 2006, and the ship ceased operation in the country. The press release cited a number of factors for the sale, including increasing fuel costs, reduced foreign arrivals "due to lack of competitive airfares," and the inability of the PNG Tourism Promotion Authority "to develop policies to protect PNG owned maritime facilities" from foreign-owned cruise ships, mainly berthed in Australia (eg, Orion Expedition Cruises, Coral Princess Cruises, and North Star Cruises Australia). ${ }^{2}$ In an online interview with Malum Nalu, a prominent Papua New Guinean blogger, Sir Peter Barter, the Australian-born nationalized citizen of Papua New Guinea and former politician who established Melanesian Travel Services, additionally attributed the decline in tourism to post-9/I I jitters about overseas travel, the global recession, and the 2002-2003 outbreak of Severe Acute Respiratory Syndrome or SARs. Barter "finally sold the Melanesian Discoverer because it was becoming almost impossible to transport our passengers to and from the ship by Air Niugini [the national airline] and charter aircraft in and out of the Sepik" (Nalu 20I0). Additionally, Papua New Guinea is often perceived as a failed, lawless state (see Hawksley 2006; Wesley-Smith 2007). The reasons for the demise of tourism are of far less consequence to Eastern Iatmul than the fact of the demise itself. And with no tourists, as local people said, there is no money.

It is not my intention to romanticize the heyday of tourism in the I980s and I990s. After all, villagers bemoaned the lack of electricity, plumbing, purified water, modern-style housing, access to paved roads, suitable health care, regular transportation to town, and fortnightly paychecks. As one man said to me in 1990 while chiseling a crocodile-shaped coffee table, "We carve for tourists because we have no real development." 
Twenty years later, I heard the very same sentiments. But the recent departure of large-scale tourism greatly amplifies the local sense of malaise. Exclamations of economic misery, and efforts to attract new tourists, now pervade almost every conversation.

In 20I0, I saw virtually no cash transactions and petty capitalism in Tambunum. The many coins and bills that circulated daily in earlier periods of my fieldwork vanished. Adults and children once wagered small change during card games. In 20I0, they gambled twine tokens. Many parents could not afford school fees. Most passbook holders, lacking the ability to make deposits, closed their savings accounts—or lost them entirely due to "hidden" monthly fees, initiated in the mid- to late-I99os, that katim katim (severely cut into) the principal. Given the absence of regional jobs, bemoaned the village school headmaster, many Eastern Iatmul see little benefit in formal education. The village lacks even the most basic health services. In the late I980s, at least a trained aid post orderly staffed a small, albeit dismally stocked aid post. Today there is neither orderly nor post. Modernity has ground to a halt. Worse, many people said, "We are going backwards."

In fact, all village tradestores are now shuttered (figure 3). Former proprietors attributed their closures to several factors, including the absence of a direct road linking the village to Wewak, the commercial hub of the province, and escalating food prices (see McGregor and Bourke 2009). Wewak contains the nearest banks, post office, hardware stores, airport, stationery store, outdoor markets, hotels, backpacker guesthouses, and other businesses, especially wholesale shops where tradestore owners procured their stock. All commerce along the middle Sepik begins and ends in Wewak. But travel to town is now so costly that tradestore owners have been unable to sustain their businesses.

To reach Wewak in 20I0, Eastern Iatmul first traveled downriver to the district headquarters of Angoram. In a dugout fitted with a 25-horsepower outboard motor, the trip lasted four hours and required eight to ten gallons of petrol-followed by another ten to fifteen gallons for the return voyage. In the late $198 \mathrm{O}$, a gallon of petrol along the middle river cost about 4.5 kina $(\mathrm{K})$ or Us $\$ 5-6$. In $20 \mathrm{IO}$, a gallon fetched $\mathrm{K} 35$ or close to US\$I 5. (In February 20IO, KI = US\$O.48, down from US\$I.I 5 in I988.) After arriving in Angoram, one paid a K2O (US\$9.60) fee to board a passenger truck for a four-hour journey over seventy-five kilometers of dirt road. Drivers also charge for cartons and sacks. Today, most Eastern Iatmul lack sufficient funds for any such travel. So costly is the trip that, 


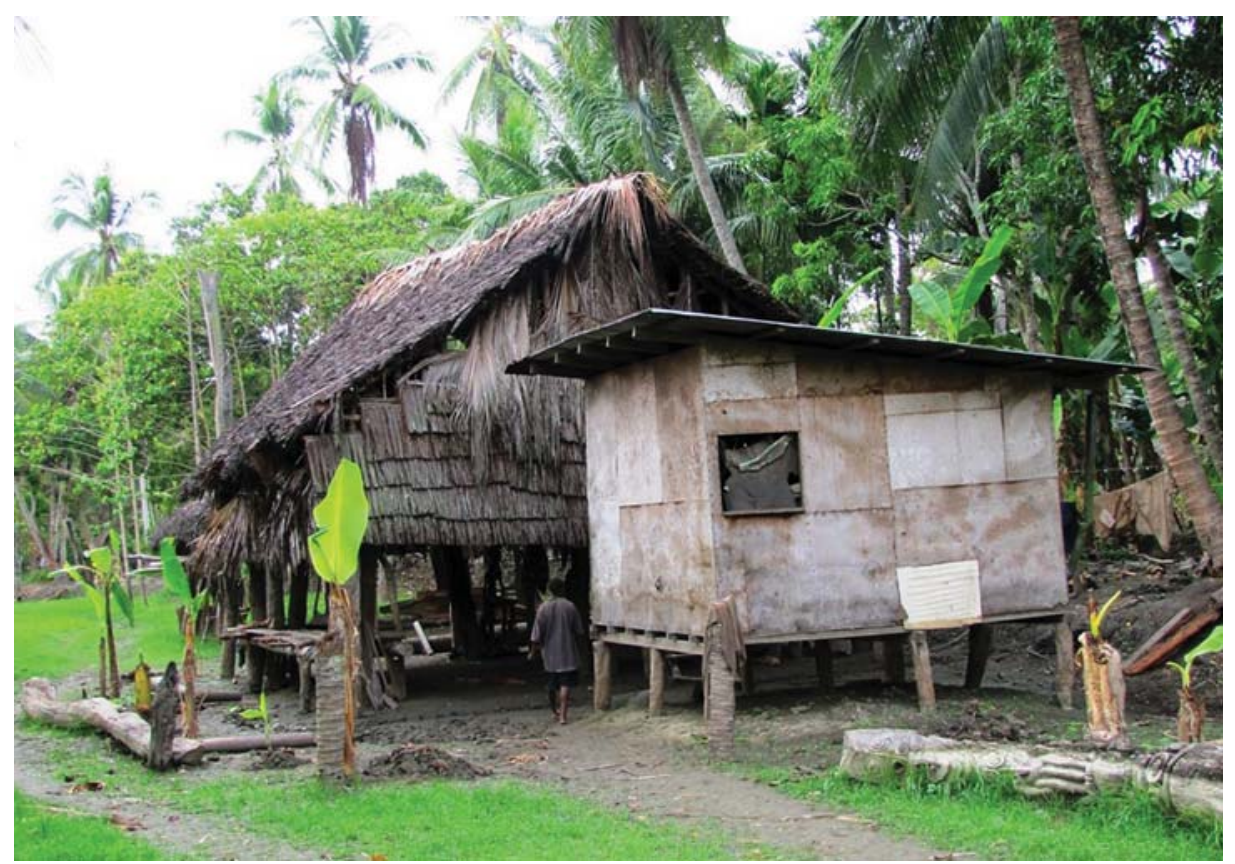

FIGURE 3 Former tradestore-empty and shuttered-in front of the owner's dwelling. Photo by author. (Tambunum, 2010)

much to my astonishment, some people in 20 Io reported walking to town and floating downriver on makeshift rafts to Angoram. Nothing like this occurred in the late I980s.

Michael Busari offered me another explanation for closing a tradestore: "Nobody has any money!" It proved extraordinarily difficult, moreover, to sustain a capitalist venture amid the moral claims of reciprocity that pervade this kinship-based society. "You can't say no to an uncle," said my village brother, himself a former tradestore owner. Every week, stated another, attempts to collect debts would result in minor squabbles and simmering resentment (liklik hevi). Most, if not all, tradestores displayed hand-written notices barring requests for credit (figure 4). One such sign added "Kam na bekim hariap. Plis mi sem long askim," or "Quickly pay your debt. Please, I am ashamed to ask." But appeals for credit were relentless-the "poison," said my brother, of the tradestore. To be sure, such "poison" existed in the I980s. But I never heard it voiced with such acidity.

The social implications of declining tourism reshape gender relations. Many Papua New Guineans vend food in open-air urban markets (Bene- 


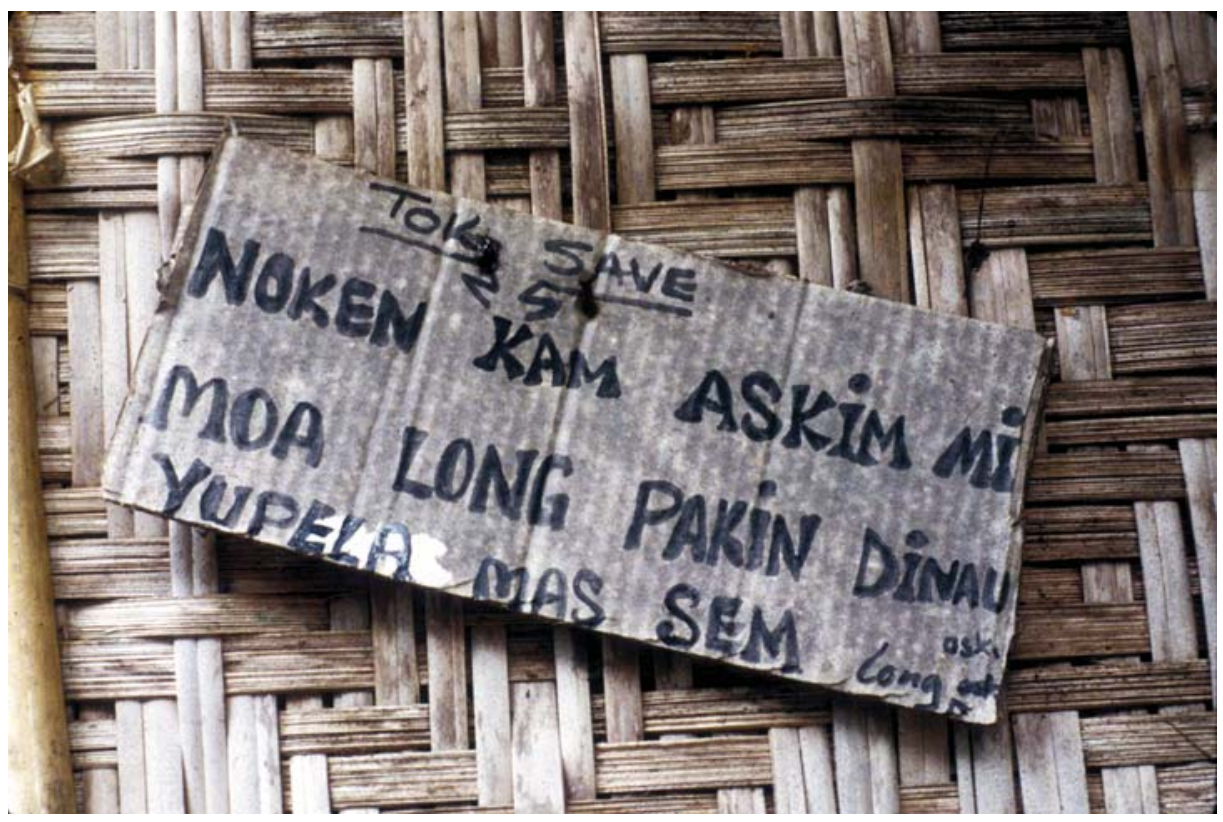

FIgURE 4 Typical tokpisin sign affixed to a tradestore declaring "Announcement: Do not ask for any more credit. Have some shame.” Photo by author. (Tambunum, I994)

diktsson 2006). Eastern Iatmul women sell baskets (figure 5). In the past, men earned greater income than women, since wood carvings fetch higher prices than basketry. The decline in tourism, however, deprives men of this revenue. Papua New Guineans themselves find little appeal in Sepik wood carvings. At best, men try to sell carvings to stores (figure 6). But this is a limited market. The main outlet for wood carvings remains overseas dealers and especially tourists. By contrast, many Papua New Guineans carry hand baskets, allowing local women who reside in town entrée into the cash economy not regularly afforded to their male kin. Were men embarrassed, I asked a group of women in Wewak? An older woman, silent until now, angrily yelled, "They should be!" A few weeks later, Dangi, one of the two wives of my village brother, derisively compared men to dogs: "All they do is laze around and eat."

Of course, men understand their plight rather differently. They now shape their masculinity partly after an ideal of middle-class paternal benevolence that includes supporting the family through wage labor and thrift. The tokpisin term famili locally connotes not a traditional kin group, such 


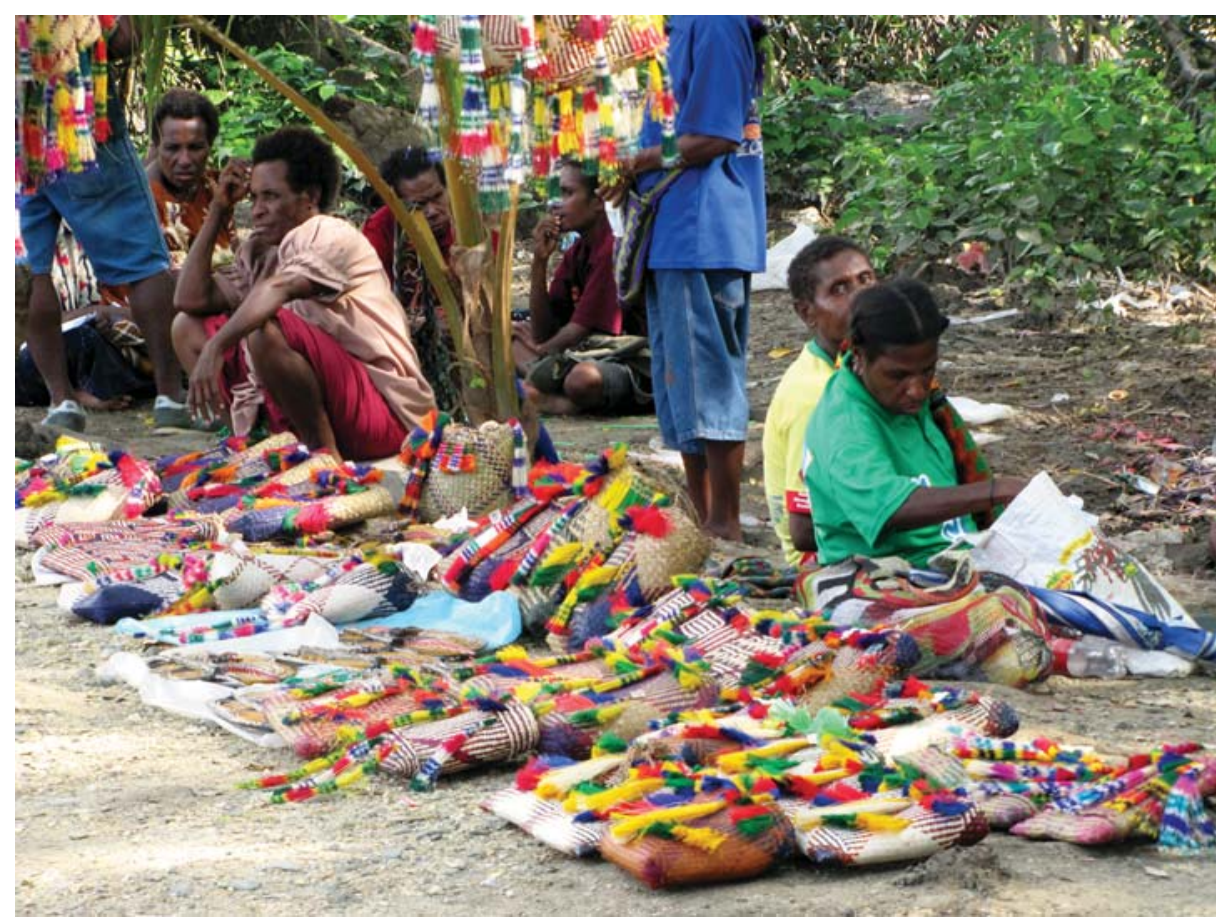

Figure 5 Women from Tambunum selling baskets by the side of the main road in town. Photo by author. (Wewak, 20ıо)

as a patrilineage or smaller "branch," but the nuclear family-a social unit that lacks a vernacular term. In the famili, as I Corinthians II:3 declares, the husband/father serves as the "head" who provides his dependants with food, clothing, school fees, and other commodities (see also Sykes 200I). The decline in tourism, however, undermines this moral ideal of modern manhood.

Men and women agree that the church, schooling, and various civic discourses promote a particular model of matrimony. A proper conjugal bond, like a well-functioning nuclear family, endures through tender affective ties and shared domestic chores. Husband and wife should unite emotionally, even spiritually, a concept known in tokpisin as wanbel, literally "one belly" (see also Gewertz and Errington I999, 7I). But feelings of masculine inadequacy, coupled to women's views of men as appetitive and slothful canines, destabilize any domestic harmony. The decline in tourism not only threatens the economic growth of the village but also thwarts the achievement of modern manhood, marriage, and the family. 


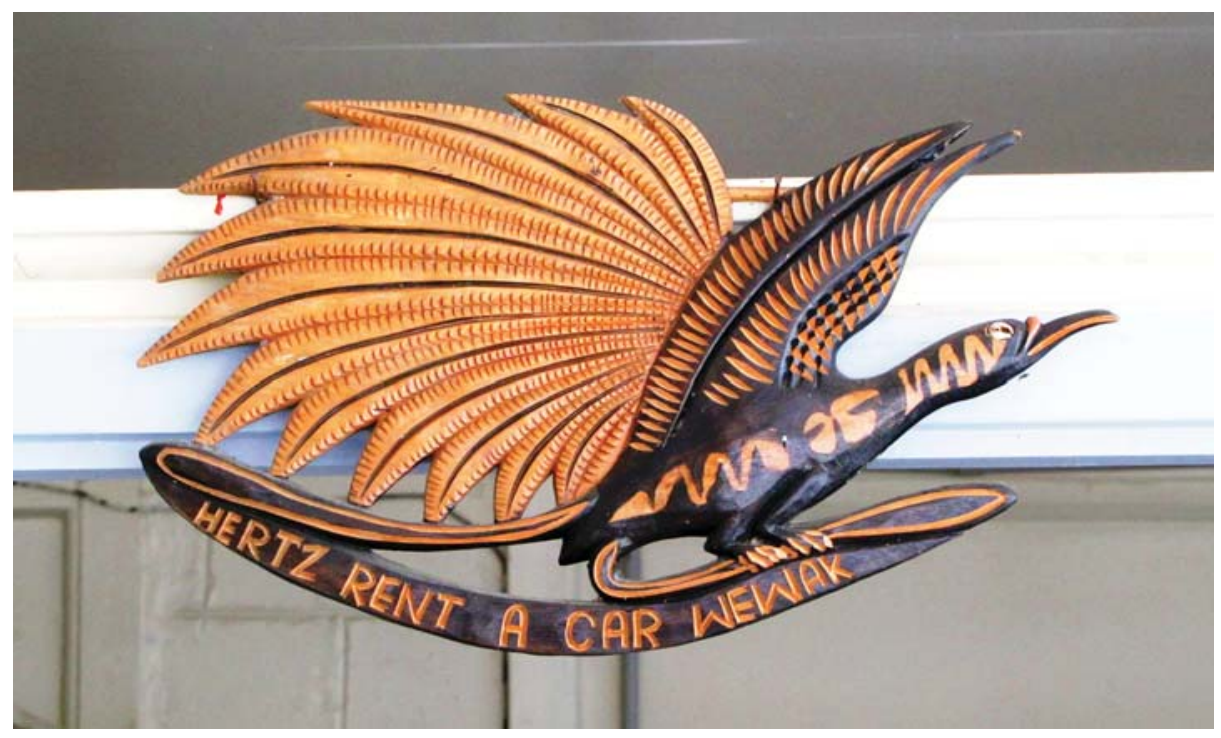

FIgURE 6 An Eastern Iatmul carving hanging above the counter in a car rental agency in town. Photo by author. (Wewak, 2010)

Reports of masculine inadequacy are common in postcolonial Papua New Guinea (eg, Clark I989; Zimmer-Tamakoshi I997; Lipset 2009). In Tambunum, this predicament calls to mind a myth about a lonely ancestor named Migaimeli who carved himself a spouse. But the wooden figure remained inanimate. Worse, Migaimeli was shamefully caught in the act, as it were, with his sculpture. Out of sheer pity, a nearby village offered him a human wife. Like Migaimeli, men in Tambunum feel unmanned, vulnerable, and frustrated. But unlike Migaimeli, men today know well what to do with their wood carvings: sell them to tourists. If only they could. Instead, and like Migaimeli again, they are largely unable today to transform their sculptures into viable sociality.

Tourism in the Sepik is a complex process resistant to moral reductionism. Many men in Tambunum pin the attainment of modern manhood and the viability of their postcolonial culture on the ability to attract tourists and thus money and renown. Most viewers of Cannibal Tours wish that the tourists would go home. But any such conclusion violates the aspirations of Eastern Iatmul-some of the very people featured in the film-who see the lack of tourism as a key reason for underdevelopment. As my anguished village brother asked, "What are we doing wrong that we live this way?" 


\section{Roads and Cleanliness}

The Sepik River annually floods during the rainy season. In 2009-20I0, the deluge rose to heights unseen for a generation, disastrously inundating the region for months. Almost all Eastern Iatmul fled to the higher grasslands. The young son of my village brother, playing in the tall grass, was set upon by an adder. He died in his mother's lap.

The flood destroyed all gardens and fruit trees. When I arrived in the Sepik in 20I0, villagers dined solely on sago starch, river fish, and greens. The community regressed to subsistence farming-much like, they often said, their premodern ancestors. With no tradestores, moreover, and no money to travel to Wewak, Eastern Iatmul were unable to supplement this paltry diet with packaged and canned foods. This is why, to invoke Cannibal Tours, local people want touristic money.

The overflowing Sepik added misery to an already desperate financial situation. No government assistance arrived during the flood. The prime minister, I was told, did nothing-even though he himself hails from the Sepik. Allegedly, he casually dismissed any suffering, saying, "The riverfolk are used to this." People in Tambunum were livid. Facing all of this, the village in 2010 felt doubly forsaken by the world.

The deluge invested tourism with new urgency. The annual flooding foils efforts to grow coffee or rubber, two common cash crops in Melanesia. A vanilla boom in the early 2000 s afforded some dividends. But the market crashed in 2004, largely due to a global glut but also, said Eastern Iatmul, because unscrupulous growers in the province carelessly cured the beans and padded their sacks with metal objects. After the flood some men planted cacao, the only viable cash crop. But several years will elapse before the growth of beans, and cacao remains vulnerable to flooding. Crocodile farms also hold promise, but they require substantial investment in water pumps and other equipment. None exist in the village. As many men see it, tourist art is the only local resource that can reliably generate money.

In discussing their economic plight, Eastern Iatmul repeatedly summoned the image of a "road." They specifically bemoaned the absence of a "path" that would lead to a variety of goals and destinations, including Wewak, tourism, money, and "development" more generally. The local salience of a road arises partly from the traditional parsing of reality into distinct paths pertaining to the living, the dead, and various spirits (see 
also Bateson I936, 237). Today, reported Linus Apingari, Eastern Iatmul choose among several lifestyle paths, including tradition, the Church, and the "new" - a catchall phrase that refers to the general idea of modernity. Each path entails unique, often competing moral tenets. When Iatmul today speak about a road, they desire not solely a thoroughfare to Wewak. They also seek to find their way in the contemporary world.

The rhetorical quest for a path also comments on the still-undisclosed source of Western affluence. Iatmul, like many peoples across Melanesia and Aboriginal Australia, conceptualize esoterica through an inside/ outside dichotomy. An outer layer of public or surface knowledge always conceals more powerful secret or "inside" knowledge. Similarly, humans dwell on the top of reality; spirits reside underneath. The inner is always more valid and truthful than the outer. Eastern Iatmul today lack a "road" because Westerners refuse to make visible the hidden wellspring of money, commodities, and the plentitude of modernity.

Eastern Iatmul also bemoan their impoverishment through an internal moral discourse. In 2010, they repeatedly referred to their clothing and bodies as "dirty." This filth communicates a collective inability to achieve the ideals of hygiene so important to colonial regimes and postcolonial notions of civility and citizenship (eg, Burke I996; Foster 2002, 25-35; Bashkow 2006, IоI). This dirt, like Lady Macbeth's accursed spot, betokens moral failure.

Filth also evokes another failing. Eastern Iatmul highly value bathing. They deride their bush-dwelling neighbors, who lack ready access to water, as malodorous and grubby. By hurling the very same scorn onto themselves, Tambunum villagers appear to deny their status as true Iatmul who keep clean and abide by the principles of proper sociality. Cleanliness, too, signals maturity rather than childhood, the ability to walk competently without tumbling to the ground, and a general sense of maternal-like care for others (Silverman 200Ic, 95, I25-I 27). Soiled clothes, then, signify the doubled failure to attain modernity and to retain the basic premises of Iatmul identity.

The recent idiom of filthiness, too, recalls Lord Chesterfield's dictum, made famous by Freud, that "dirt is matter out of place." Contemporary concerns with filth in Tambunum convey the broader self-assessment that the community is "out of place," located neither in the traditional past (unclothed yet clean) nor in the modern future (clothed and laundered). A "road" to "cleanliness" would reposition the village in the landscape of modernity without relinquishing tradition. 


\section{Mr Thinker, Sepik Souls, and an Airport Crocodile}

Perhaps the most insightful moment in Cannibal Tours occurs when a Sepik man quips, "We live between two worlds." Nowhere is this liminal worldview better illustrated than in tourist art. Despite declining visitors, Eastern Iatmul continue to produce wood carvings and baskets that express emergent, transformative, often contrary and hybrid facets of self and society (see also Silverman 200Ia, 2004). Similar aesthetic messages occur elsewhere in Melanesia and Island Southeast Asia (eg, Coiffier I992; Otto and Verloop 1996; Causey 2003; Dougoud 2005; Adams 2006; Adams and Sanchez 2008). In Tambunum, carvers blend conventional motifs and forms into idiosyncratic styles and patterns. These objects represent not the totemic ancestors of patrilineal descent groups but rather the self as an independent, inventive agent.

Descent groups, even today, never fashion their own sacra (sacred items) lest they dangerously violate "customary law." Instead, a group feeds the lineages of their sisters' children and hereditary ritual partners, who reciprocate by creating or primping the necessary spirit. Sacra therefore represent the foundational trope of Melanesian sociality, namely, reciprocity. By contrast, touristic wood carvings represent an individual's labor, aesthetic vision, and monetary desires. While magical sculptures benefit the group, tourist art allows men to pursue the magic of modern self-making.

Iatmul, as Gregory Bateson noted long ago (I936), value headstrong individualism. But cultic spirits and taboos constrained youthful male agency. Not so today, remarked my friend Gamboromiawan while telling a Melanesian rendition of the Horatio Alger tale. Any kid can now grab a chisel, fetch a hunk of wood, and set off for the town or city to peddle tourist art. Despite the fact that this enterprise is locally seen as "not real development," many Eastern Iatmul understand tourism as enabling men-and also women with their baskets-to craft a modern sense of identity that pivots on economic self-reliance, autonomy, and the pursuit of adventure.

Objects intended for external consumption lack totemic names and, hence, ancestral oversight and magical ensorcellment. As a result, tourist art adheres to few rules. In this sense, tourist art resembles the community at large since "customary law" (kastom lo), people now say, lacks the efficacy to restrain individualism, promote cooperation, and allow 
for self-governance. Tourist art mirrors and assists this broader selfassessment of a dramatic shift in the norms of personhood and especially masculinity.

Eastern Iatmul, like many Melanesian societies (eg, Bashkow 2006), view social harmony as a perquisite to prosperity. Discord subverts communal "development." Thus Linus Apingari criticized young people as the "wokabaut generation" that pursues unfettered self-pleasure by mixing homebrew, attending all-night discos, stealing from gardens, and smoking marijuana (see Lipset 2006). Eastern Iatmul also bemoan the introduction of another antisocial practice: charging interest for small loans ( $\mathrm{K}_{3}$ for every KIO advanced). We must understand tourist art, I am suggesting, in terms of wider shifts in personhood and sociality that entail contrary moral discourses (see also Gewertz and Errington I999; Martin 2007).

In 1994, a group of Sepik men, including a trio from Tambunum, traveled to Stanford University for six months to create the New Guinea Sculpture Garden (Silverman 2003). The campus boasts an original bronze cast of Rodin's The Thinker. My friend Gamboromiawan thought he could do one better and so sculpted a Iatmul version in California. In 20I0, Gamboromiawan's son, Peter Marus, packed a canoe with wood carvings and paddled to Angoram, where he sold the vessel for $\mathrm{K} 300$ (US\$I 44). He paid for truck transport to Wewak and then booked steamship passage to the coastal city of Lae. There, Peter sold some carvings and used the proceeds to fly to Port Moresby, the capital city. Much to my surprise, the PostCourier, a national daily, ran a vignette in April 20 I I about Peter selling a "Mr Thinker" sculpture outside the Boroko Foodworld supermarket in Port Moresby for KI,500 (US\$720) (Hriehwazi 20II). The "masterpiece" was purchased the next day and placed inside the foyer between two restaurants, Seoul House and Thai House (figure 7)—a successful positioning of Iatmul tourist art amid a transnational Melanesian modernity.

Peter, like many men in Tambunum, sees touristic wood carving as enabling a degree of masculine agency unknown in earlier eras. Peter is a self-made Melanesian man-albeit a man who, in this instance, sculpted his self-sufficiency after an image by his father. Print advertisements in Wewak similarly tie individualism and individuation to modernity. "It's your time," declared a poster for Pepsi, "the choice of a New Generation." Or, as public health promotion for Seif Raida Kondoms counseled, "Make the right choice." Tourism is another venue for making modern choices.

Peter's father, Gamboromiawan, also known as Simon Marmus, resides 


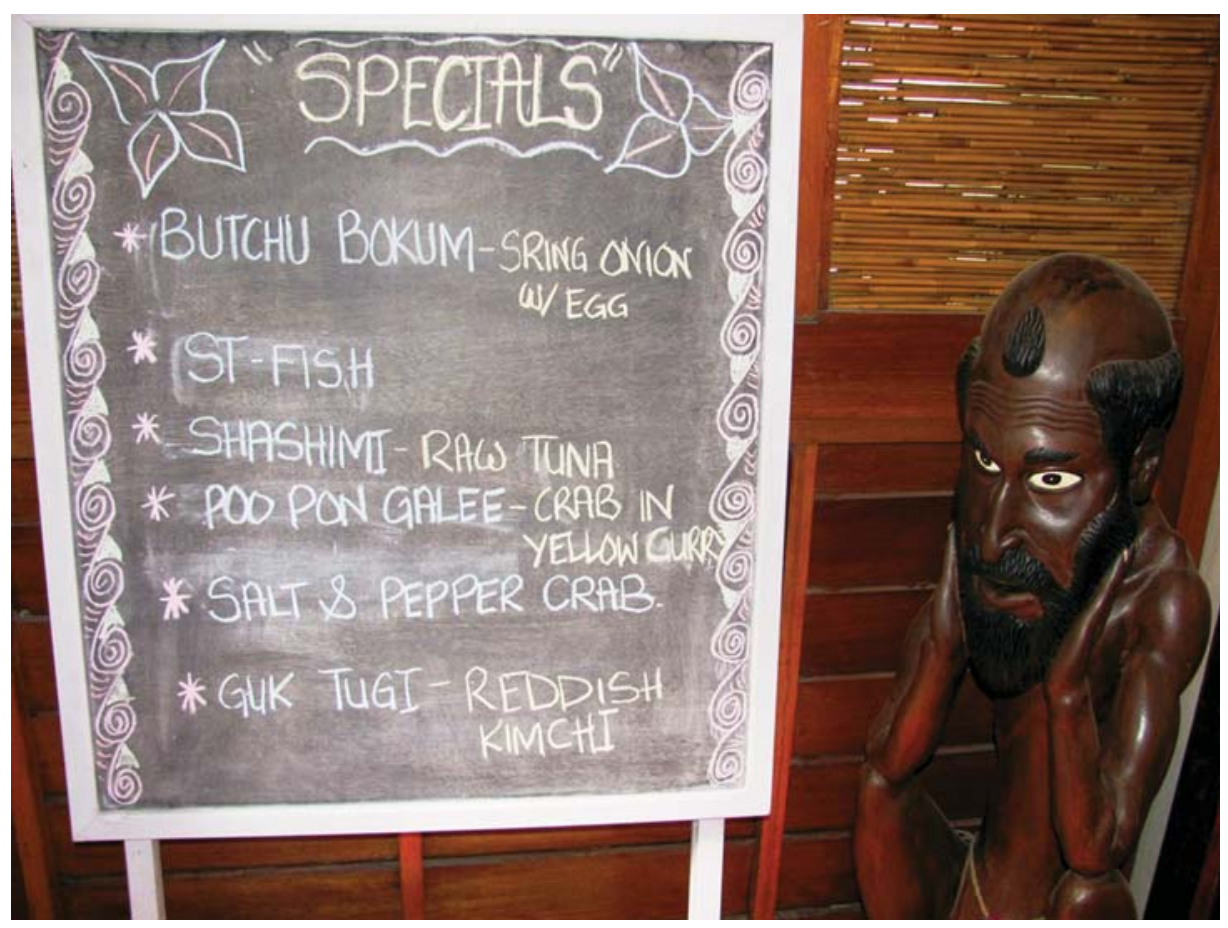

FIgure 7 Peter Marus's Mr Thinker sculpture, sitting in the foyer between two restaurants in Port Moresby, the capital city of Papua New Guinea. The carving was modeled after his father's rendition of Rodin's The Thinker at the New Guinea Sculpture Garden, Stanford University. Photo by Don Niles and used with his permission. (Port Moresby, 201 2)

in a small, rickety village dwelling that in 20 Io seemed likely to topple on its posts. Much of Simon's selfhood arises from former successes in carving for Western audiences, including visitors to the New Guinea Sculpture Garden at Stanford University. For that monumental effort, he has but a few faded photos and a keepsake plaque (figure 8). Simon's sons reside in different cities of the country, flogging tourist art, pursuing the same modern self-interest that once accorded Simon a modicum of fame. Simon, lonely and impoverished, feels rejected by the wider world that once celebrated his talents. He also suffers the recent death of his wife and the departure of his sons. Do they send you money, I asked? "No." Simon then begrudgingly acknowledged the sway of touristic individualism: "It's their choice. I can't tell them what to do."

In various ways, as Simon and his son Peter attested, men's touristic 


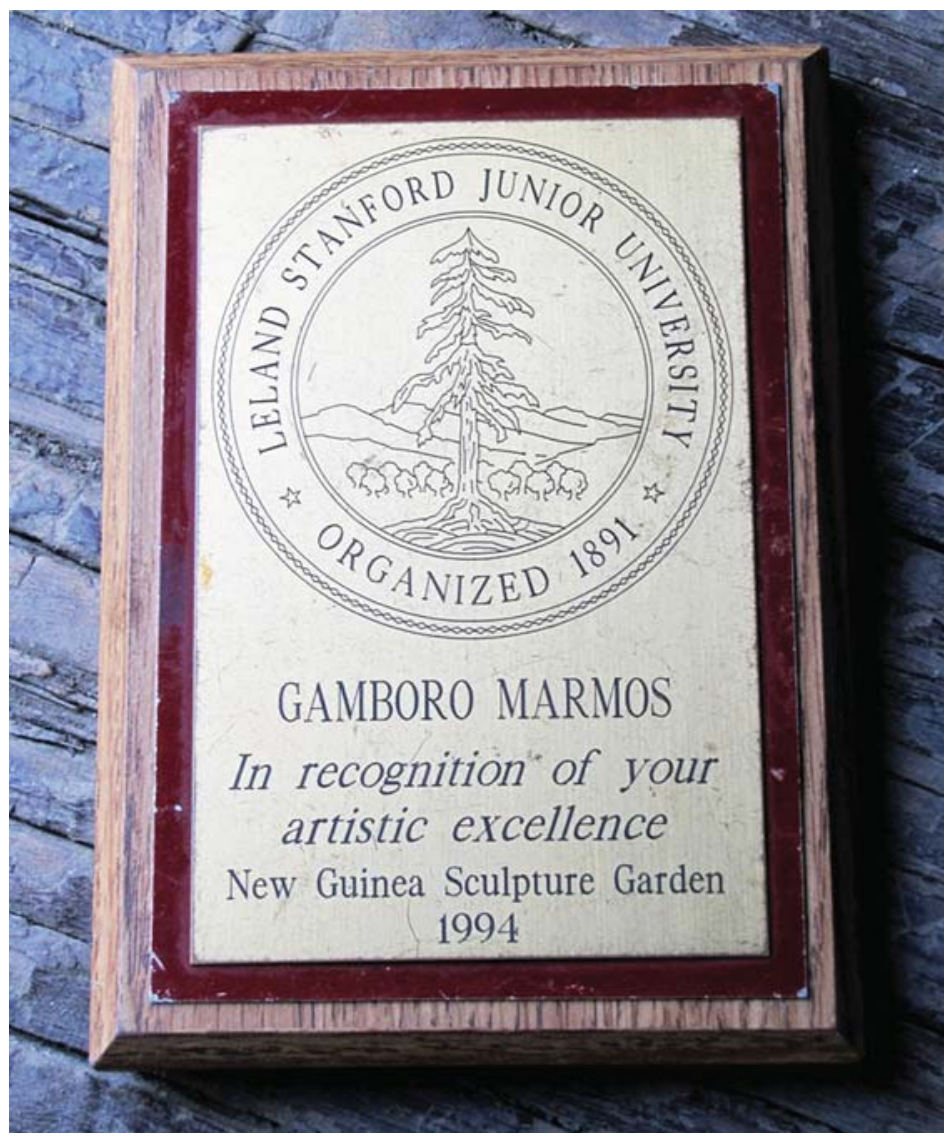

FIgURE 8 Commemorative gift, normally hidden in a tattered suitcase, in honor of Simon Gamboromiawan Marmus's artistic renown. Photo by author. (Tambunum, 2010)

wood carvings often express the self as a modern, autonomous agentsometimes leading to success, sometimes to miserable solitude. Women's basketry represents a different facet of contemporary identity. Women often weave Christian crosses into their baskets as well as the initials "PS," an abbreviation for "Pikinini Sepik," the tokpisin phrase for "Sepik child." Recently, baskets also proclaim "Sepik Souls" (figure 9). This iconography defines identity with reference to a regional, multiethnic political unit initially defined through colonial regimes of knowledge associated with the state, such as bureaucratic governance and even anthropology. The alliterative phrase "Sepik Souls" also evokes Christian notions of immortality. 


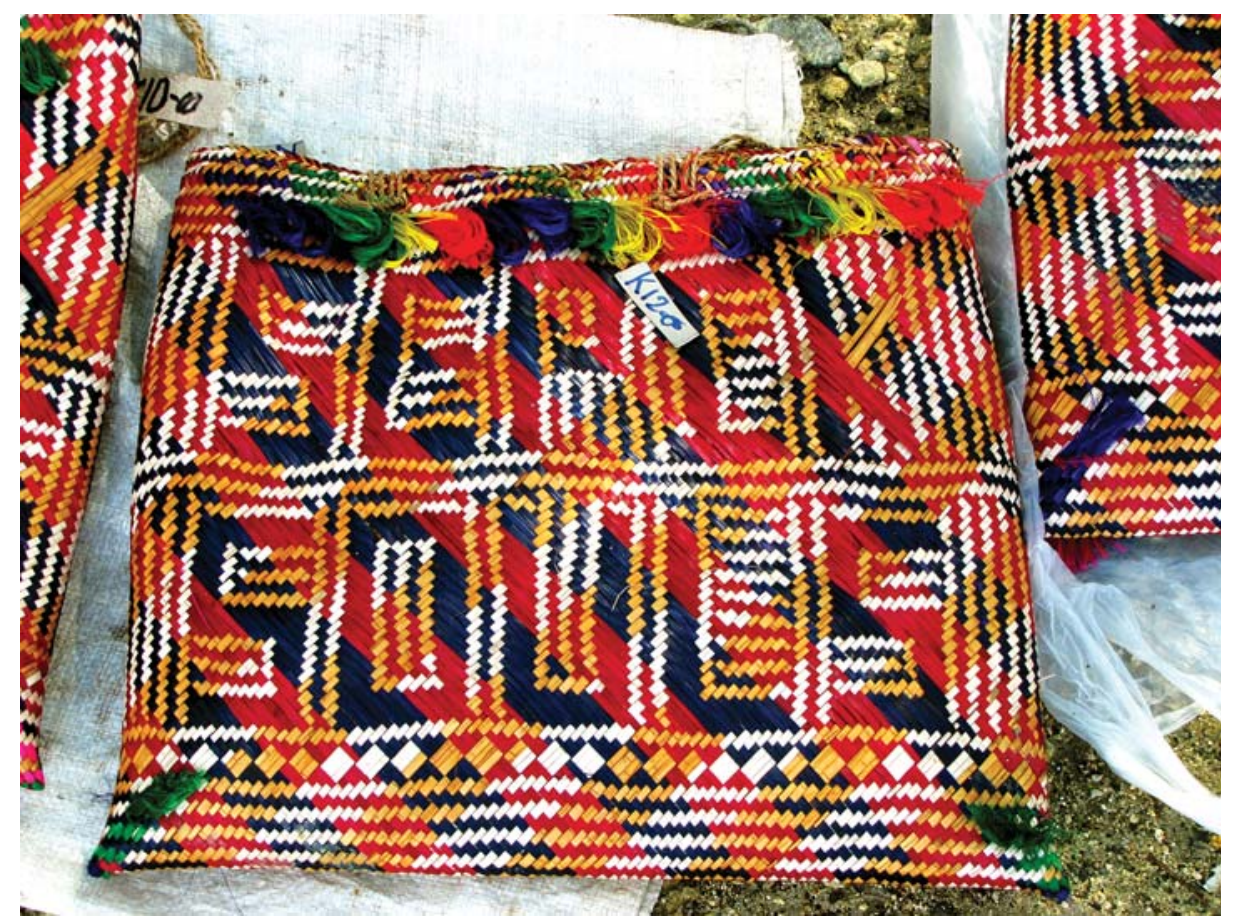

FIGURE 9 "Sepik Souls" basket sold in the town marketplace for KI 2.00 (Us\$5.76). Photo by author. (Wewak, 20IO)

Men similarly carve, beneath variations of the national emblem, phrases such as "I Love the Lord My God," "God Bless Our Home," and "Hail Mary Pray for Us." We can also read these slogans as local attempts to affirm cross-cultural similarity despite the enormity of global and touristic inequalities - to negotiate relations of "commensurate differences," to draw on Deborah Gewertz and Frederick Errington (I99I), in a world system predicated on "incommensurate differences."

Perhaps the most common motif on touristic wood carvings is the crocodile. In the traditional cosmology, crocodile spirits dominate the pantheon of each patriclan. But in popular imagery throughout Papua New Guinea, these aquatic reptiles serve as the de facto mascots of pan-Sepik identity. Such insignia appear on the provincial flag, for example, and the one kina coin. Yet I caution against any simplistic reading of this motif. In a particular touristic genre, crocodiles appear to crawl out of the maw or surface of the mask. One such Eastern Iatmul carving hangs inside the 


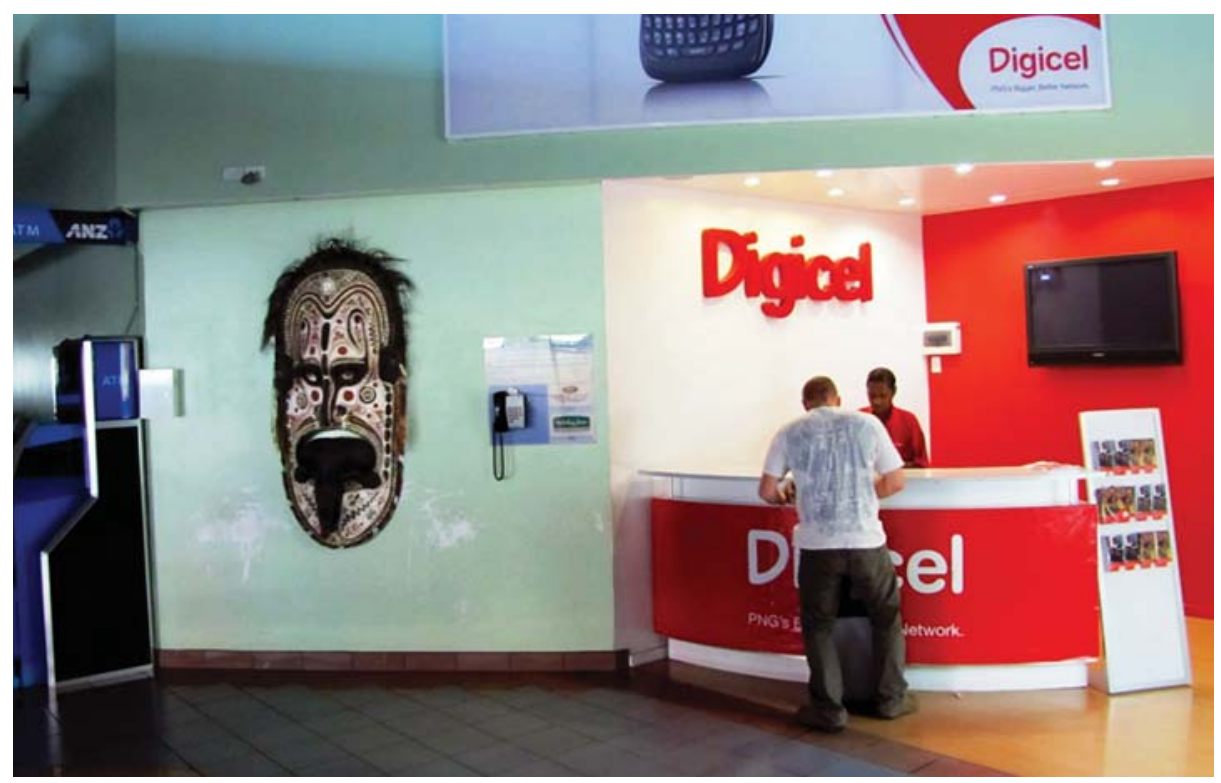

Figure ıо. A Sepik crocodile mask hanging in Jacksons International Airport. Photo by author. (Port Moresby, 2010)

International Terminal at Jacksons International Airport in Port Moresby, sandwiched between an automated teller for the ANZ bank and the kiosk for Digicel mobile phones (figure Io). The emerging crocodile on this gargantuan mask seemingly seeks a place for Sepik identity amid two salient forms of modern magic: mobile telephony-which does not yet fully reach the village-and the dispensing of cash from an unseen source inside a machine.

The half-hidden image of the touristic crocodile visualizes the local ontology of totemic esoterica in which, as I discussed earlier, a veneer of public knowledge screens more accurate unseen truths. Thus framed, the touristic crocodile represents the unfinished, ongoing formation of contemporary Sepik personhood. But these sculptures also appear to dramatize the local understanding that the "path" to modern success has yet to be fully revealed. The touristic crocodile, in other words, represents the unattainable goal of "development."

The motivation for creating tourist art is singularly economic. It would be factitious to suggest otherwise. But monetary motivation, I've shown, does not erode symbolic meaning-quite the contrary. Tourist art materi- 
alizes emergent, postcolonial forms of self, society, and sociality. To some degree, the frustration associated with declining visitors arises precisely from the fact that tourism is a key public arena in which Eastern Iatmul express cultural hybridity to themselves and to the wider world.

\section{Moikuadu and the Sepik Cultural Diversity Show}

The clash between kastom lo and the aspirations for development seemed particularly acute in $20 \mathrm{IO}$ as the village prepared for a regional festival. Some months prior to my visit, a "culture group" from Tambunum, called Moikuadu, pooled $\mathrm{K}_{5} \mathrm{O}$ (US\$24) and formally registered as a business with the Division of Commerce and Tourism Industry of the East Sepik Provincial Administration. The name of the group, a neologism, serves as an acronym for three lineages of the Sago Clan (Mboey Nagusamay): Moim, Kwassa, and Dimiri. Their goal in registering was to enlist financial support from the government for "culture and tourism" activities.

After incorporation, one of the leaders of the group canoed to Angoram and approached the Angoram-Middle Sepik Local-Level Government to announce the completion of a new men's house in Tambunum, called Wyngwariimbiit (figure II). The "culture group," mindful that the promotion of traditional culture is a nationwide priority, invited provincial and national politicians as well as the media to attend the opening ceremony or singsing for the men's house. The event promised to open a "road" to tourism, money, and renown.

On I 5 July 20I0, male representatives from the local-level government arrived in the village by fiberglass dingy. They entered the all-male cult house-foiling, of course, participation by local women-to report that the organizers of an upcoming "Sepik Cultural Diversity Show" agreed to include the singsing for the new men's house. Most events during the show would take place in Angoram: traditional handicrafts, a display of sago processing, "string band" and "rock band" competitions, and a "Ms. Sepik Quest.” On 6 August, however, local and national politicians would disembark in Tambunum to view the singsing. Even Prime Minister Michael Somare might attend! This would be Tambunum's moment. Fail, villagers were told, and you will not receive this opportunity again.

Quickly, the singsing took on the tones of a classic cargo cult. First, Eastern Iatmul believed that the ceremony would result in the "government" restoring tourism. Second, the performance would garner such renown that Tambunum would receive all-expense-paid invitations to 


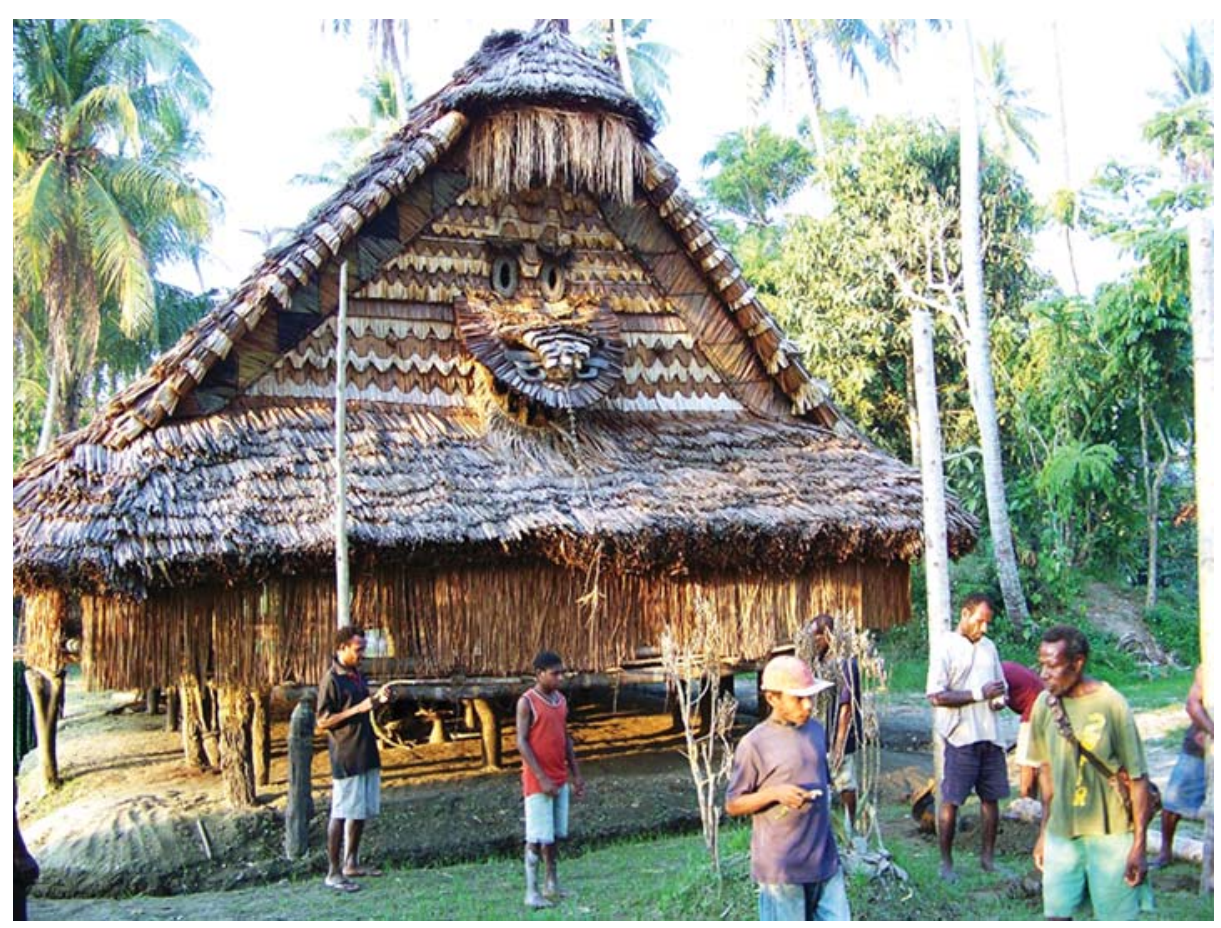

FIGURE I I Preparing a platform in front of a new men's house for an opening ceremony scheduled for the yet-to-occur Sepik Cultural Diversity Show.

Photo by author. (Tambunum, 2010)

perform at other festivals throughout the country and even overseas. Last, the singsing would so impress the visiting dignitaries that the local-level government would fund the construction of a "traditional art gallery" in the village. This, too, would "pull" tourists as well as "anthropologists" and "geographers," whose writings, speeches, and universities would likewise bring the village acclaim, tourists, and "development."

Despite this runaway utopianism, local politics soon held sway. A spokesman for the Moikuadu culture group announced in the new men's house that the singsing would include two dances, representing two of the three clans of the village. Dissent was immediate. "What culture group?" "We never heard about this!" "Who gave you the right to broker on behalf of the village?" "Why not include the entire community?" The collective yearning for touristic success swiftly unraveled amid egalitarian sentiments and the Iatmul propensity for divisiveness that Bateson dubbed "schismogenesis" (1936). 
The Moikuadu culture group also declared their intention to perform their signature eagle dance at the singsing, featuring a pair of ensorcelled costumes that depict two avian spirits. The lineage (Moim) that owns the elder-brother eagle helped establish the culture group and so eagerly prepared for the singsing. The lineage that claims the younger-brother eagle, however, threatened nonparticipation. Several years ago, the Sago Clan staged a singsing for an audience from the Melanesian Discoverer. The lineages that eventually registered as the "culture group" in that instance, however, unevenly distributed the proceeds. Not only did the slighted group, Kavelage, suffer humiliation, but the deception amounted to a public repudiation of their totemic legitimacy. Consequently, their eagle would not dance at the culture show.

With the retreat of the Kavelage lineage, the ceremony seemed destined to fail-dangerously so. The two eagle spirits are siblings; they dance as a duet. To violate this convention might invite the ire of the very spirits the dance should celebrate. In fact, as we will see shortly, much about the upcoming singsing was fraught with mystical uncertainty. The retention of tradition, at once a draw for tourism, equally threatened the "road" to success.

Most Eastern Iatmul believed that the local-level government, aided by provincial and national authorities, would gift the village a sizable sum of cash for the singsing. I heard mention of tens of thousands of dollars. The Moikuadu culture group announced its intention to deposit some of this windfall into a savings account in Wewak earmarked for village-wide endeavors. But most villagers took this claim as a ploy to replicate the earlier swindle. To this, Moikuadu angrily berated the other groups for their sloth. "We took the initiative to organize the singsing! We registered with the government! We walked to Wewak to pay the registration fee and to grease (gris) the palms of the man employed at the district commerce office! And we built the new men's house!" Given all this, "we earned the right to oversee the profits from the ceremony!" And then, as if to affirm all misgivings, the culture group added that they would naturally reserve some of the proceeds for themselves.

The dispute entailed competing claims to money but also, yet again, to validation. In 2009, the Community Water Transport Project, funded by the Asian Development Bank, the PNG Government, and the OPEC Fund for International Development, launched a new steamship owned by Lutheran Shipping, the mV Siddy, to serve Sepik communities and the coastal towns 
of Wewak and Madang. Some Eastern Iatmul canoed to the nearby village of Timbunke to dance in the launching festivities. Simon Marmus, as it happened, strutted at the front of the line, and for this reason was approached by a newspaper reporter. During the interview, Simon mentioned his participation in the New Guinea Sculpture Garden. Intrigued, the reporter arranged a subsequent conversation in Wewak, wherein he suggested that Tambunum register a formal culture group with provincial authorities. This way, the village would become eligible to receive government funds aimed at fostering "custom and culture." On this basis, Simon publicly insisted that he alone was responsible for the singsing and thus entitled to control any associated revenue. For him, as for many men, the singsing promised redemption in the post-touristic Sepik.

Of course, the dissident lineage, Kavelage, also desired recognition as a legitimate voice and stakeholder in tourism and village politics. Long ago, according to one version of history, the Kwassa lineage of the Sago Clan, and signatory to the "culture group," agreed to loan the younger-brother eagle spirit to Kavelage. This gift also included totemic names and land. Over time, however, Kavelage unjustly asserted title to these assets as well as undue authority within the clan. For this hubris, the group deserved nothing less than marginalization. But Kavelage avows a different history in which the eagle, land, and names were originally theirs and wrongly appropriated by rivals.

Several years ago, the Sago Clan arranged a formal debate inside a men's house to resolve this dispute. But oratory turned to blows-an egregious transgression in the sacred enclosure-and Kavelage suffered further disrepute. In response, the group withdrew from public life, relocated across the river, and shunned construction of the new men's house. In 20IO, they refused even to enter the building-thus acting, said my village brother disdainfully, "like women and children." For these reasons, the culture group refused to recognize Kavelage as an equal partner in the singsing — and Kavelage rightly expected any participation to result in an unfair recompense.

Normally, as I mentioned earlier, kin groups never perform their own ceremonies or create their own sacra. Nor should they build their own men's houses. Rather, a group provisions other clans who reciprocate with ritual or labor. The Sago Clan, however, espousing the modern value of expediency, dispensed with this custom; they constructed their own men's house. This innovative and collective act of touristic self-making, a clear 
breach of ritual etiquette, did not sit well with others, and imbued the men's house and the entire singsing with an aura of moral uncertainty.

One night, Henry Gawi privately disclosed another transgression. The Sago Clan attached an eagle-shaped roof finial atop the building-a normal practice in the middle Sepik. Many generations ago, however, this same clan accidentally torched a different men's house during a brawl-long before the establishment of Tambunum (see Newton 1997). Ever since, the clan was unable to perch an eagle above their cult houses lest they offend the presiding spirits. But they violated this prohibition in 20I0, and thus anybody who participates in the opening singsing, declared Henry, is "stupid." Linus Apingari concurred, but for another reason. The two eagle costumes that would dance during the singsing serve as "spiritual containers," he said, and thus demand careful attention to ceremonial protocol. But Linus heard a rumor that the Sago Clan might open the singsing by slaughtering a dog, then a pig at the conclusion-perilously reversing tradition. Linus not only said that the organizers of the singsing were "careless" but also voiced no desire to serve as a "stepping-stone" to their monetary gain.

The weeks unfolded through a series of meetings in various village cult houses to deliberate the singsing and to resolve a cascade of disputes. Women dyed and braided brightly colored fiber skirts and mended shell ornaments. Younger men practiced their songs. Through it all, the singsing became increasingly invested with earnest hopes of opening a road to riches and renown. Toward the end of July, news arrived from Angoram that the festival was delayed until Independence Day (I6 September). In September, as I learned by e-mail, the Sepik Cultural Diversity Show was again postponed. As of January 20I3, the show has yet to occur. The road to touristic prosperity promised by the festival remains, like the path to modernity, unseen and impassable.

The cargoistic innuendo of the singsing was perhaps best stated by Simon Marmus Gamboromiawan. The newspaper reporter who interviewed Simon stated his intention to attend the singsing and subsequently to post photographs of the event on the Internet. Tourists, museums, and teachers from around the world, Simon maintained, will glimpse the photos and pay for Tambunum villagers to travel, perform, and construct new sculpture gardens, resulting in money, fame, and tourism. Eventually, I privately asked Simon if he had ever seen the Internet. "No." But he remained undeterred. Cyberspace thus became yet another modern road to development and affluence in the post-touristic Sepik. 


\section{Ghosts, Tourists, And the Road to Cargo}

One night, while chatting with my village brother Kamboi, I learned about the moral critique of underdevelopment preached by the local catechist. If you raise your "spiritual side" and join with Jesus, everything good will follow. But if your spiritual side goes down, all will fall into ruin. Raising your spiritual side requires cooperation, respect for others, regular church attendance, and the expulsion of one's "evil spirit" in the name of Jesus. Villagers must also cease "believing" in traditional wood carvings. These are "false gods," made by humans, and thus "dead." Worse, the sculptures embody "evil spirits" that dwell in the ground. Such beliefs condemn the village to impoverishment. Instead, villagers must unite their hearts-live wanbel - with Jesus. When that happens, Jesus will return with the dead and bring prosperity.

Many Melanesian societies today attribute their material impoverishment to notions of moral imperfection within a Christian worldview (eg, Smith 1994; Robbins 2004, 208-209). Thus several communities in Vanuatu recently staged reconciliation or forgiveness ceremonies, often in churches, to remove "curses" that arose from the early mistreatment of missionaries (Eriksen forthcoming). These "curses" continue to stymie development. Many Melanesian societies, too, link the dead with affluence. Eastern Iatmul generally fit this pattern. But people in Tambunum now add a novel element to this widespread millenarian plot: tourism. To understand this element, we need first consider the origin of death.

In Eastern Iatmul myth, the first person to die was an ancestress named Avawundumbu. In the late I980s, I extensively studied funerary ritual and listened to this tale many times. I knew that Avawundumbu established the village of the dead, then barred the living from visiting deceased kin by blocking the road with a broken canoe. I knew that the newly deceased are boiled in water at the deathly village to slough off their black skin, leaving a white, bone-like, ghostly appearance that explains the affinity, common throughout Melanesia, between Europeans and the dead (eg, Leavitt 2000). But in 2010, I learned something new: Avawundumbu will someday lead the dead back to the living. Not only will the deceased display white skin, but they will also converse in a new tongue.

In 20I0, the village was awash in conversations about the dead, far more so than in my earlier periods of fieldwork. Many Eastern Iatmul reported dreaming about the place of the dead—a place resembling a vibrant city, 
full of cars, packaged food, technology, commodities, and money. "Now we think the dead live in America," I was told. When Avawundumbu returns, she will remove the broken canoe, thus opening the "road." Villagers will then be able to visit the dead and finally obtain the goods and cash they desperately seek. Never before had I heard cargoistic sentiments in Tambunum.

I also learned that the dead sometimes visit. They arrive in the swamp behind the village, travelling on a shimmering, supernatural ship that resembles, people said, the Melanesian Discoverer. Allegedly, one can sometimes perceive mysterious sounds and lights in the marsh, especially when someone nears death. Inside the vessel are goods. But if you reach for something, it all disappears-an allegory, I suggest, for the state of development in the post-touristic Sepik. Deceased kin, in other words, double for the absent tourists. Indeed, the dead enjoy what the living in Tambunum have yet to experience: the material plentitude of modernity.

Some former tourists, I was also told, were not really tourists at all-or not in the conventional sense. They were dead kin, returning to the village for a quick reunion, dressed in their new skin and speaking a new language-just as the myth foretold! Here, the inviolable boundary between white and black, so crucial to the colonial era, blurs through a type of postmortem, epidermal cross-dressing (see also Bashkow 2006). In Cannibal Tours, one Sepik man similarly tells viewers that villagers call the white-skinned tourists "the dead." Then he chuckles, saying, "We don't really believe it. It's just a phrase." But no longer is this label a mere idiom in Tambunum.

Perhaps most shocking in 2010 was the contention that ghosts are trying to bring money and goods to their living relatives. The work of grieving, in this sense, combines with unfilled commodity desires (Leavitt I995). But missionaries block the "road," then visit gravesites at night and steal the cargo. Some of my interlocutors specifically accused Australia of this nefarious subversion of reciprocity. Australia then sells the cargo — the very goods that rightfully belong to Eastern Iatmul—to Asian merchants who in turn vend the goods to destitute Papua New Guineans at exorbitant prices in the stores in town. America, I was told somewhat accusingly, knows about all this. If white people did not block the road, then Eastern Iatmul would finally enjoy cash and goods. "We would be okay. Instead, it is hard to find money.”

The convergence of race, power, money, and anxious uncertainty about the future imbued almost every conversation in 2010 with a conspirato- 
rial aura. Local people talked about the blackness of US President Barack Obama. They voiced fears about Al Qaeda "terrorists" slipping into the Sepik from Indonesia and the imminent arrival of war. I also learned that an ailing woman in nearby Timbunke village had briefly lost consciousness several years ago. For a few moments, she lay dead-but her soul espied the expatriate priest stationed at the Timbunke Catholic Mission who had recently gone overseas for a holiday-or so he said. In truth, reported the woman on awakening, the dishonest priest had actually traveled to the village of the dead to obtain a 35 -horsepower outboard motor. "He got the motor for free!" I was told. "He didn't pay! This is how the missionaries obtain their goods and money!" Shortly thereafter, the priest allegedly returned to the Sepik, hauling a new motor.

I was offered further proof for the living dead. Timbunke is the birthplace of Cherubim Alfred Dambui, the late bishop of the Roman Catholic Archdiocese of Port Moresby. Not long ago, while Bishop Dambui was in Rome, a man from his village died. When informed of this by telephone, the bishop apparently responded that he already knew about the death because he saw the deceased's ghost in the Holy City. When Dambui later visited Timbunke, local folks peppered him with questions about the ghost. Afraid, the Bishop hastily left. "He, too, knew the truth," people told me.

In 1989, one of my adoptive village mothers, Mundjiindua, presented me with a basket. I received many such baskets, so the gift was neither unusual nor particularly memorable. Not long thereafter she died. More than twenty years later, in 20I0, I was chatting with a sizable group inside the new men's house when someone asked matter-of-factly, as if such encounters with the dead happen all the time in America, if I had returned the basket. "Did you see her? Did you give her back the basket?" I was then told that I must ask the people who funded my research to unblock the road so Eastern Iatmul can also, like myself, enjoy money. "You see us now. It is hard for us to buy food, soap, laundry detergent, school fees. We are dirty. You must tell them to open the road."

The literature on cargo cults is perhaps the most enduring scholarly genre in Melanesian studies, with numerous theoretical nuances and turns (Hermann 1992; Lindstrom 2000; Otto 2009). It is not my intention here to summarize this literature, which has long pinned frustrations with development to the rise of cargoistic ideation (eg, Maher I961; Harding I967). Still, certain millenarian tropes in Tambunum recall themes reported for other communities, such as the borrowing of European symbols, tech- 
nologies, and practices to explain and redress (post)colonial inequalities (Lattas 2000). The ghostly tourist vessel, for example, laden with goods, resembles unseen submarines in the Purari Delta of Papua New Guinea and "an invisible cargo ship that monthly brings commodities to a village of ancestral spirit-beings on the coast" (Bell 2006, 228-229). The eerie tourist ship, like many millenarian vehicles, responds to modernity by seeking to contain the global within the local. Eastern Iatmul cargoism, too, following the departure of tourists, fits Bruce Knauft's thesis that "relational separatism" often catalyzes millenarianism (I978).

Regional parallels aside, Eastern Iatmul, to repeat, uniquely tether their millenarianism to tourism. ${ }^{3}$ Moreover, the anthropological record of the middle Sepik contains no references to cargoistic sentiments. Similar beliefs are reported for other parts of the East Sepik Province (Gesch I985; Leavitt 2000; Tuzin 1997; Kulick I992; Roscoe 2004). But people residing along the middle river have not, until now, dwelled in the thrall of these schemes. There is no formal cargo "cult" in Tambunum. Eastern Iatmul do not, moreover, harness their millenarianism to provincial or national politics (Ogan I974). But never before did I hear Tambunum villagers voice the conviction that Europeans erect insurmountable roadblocks to prevent local ghosts from dispensing a rightful commodity inheritance to their living heirs. Such notions existed elsewhere in Melanesia (eg, Jebens 2010), but not in the middle Sepik. Or not until now.

How did I respond to this cargoism? Frankly, I was terrified. I also knew that my interlocutors-people I have known for over two decades-were looking to me for confirmation. Clearly, as a European and white person, I was in on this grand scheme of racial embezzlement. But my friends were also hoping that I might offer them some insight into how finally to tap the riches of development. Not proudly, I remained mute, avoided their gazes, and scribbled in my notebook. My silence was tantamount to a lie at the precise moment when my anguished friends yearned to behold a clear and accessible "path" to tourism, money, and development. But the modern world system has yet to reveal any such "road." At best, Eastern Iatmul can only concoct a nightmarish dreamscape about post-touristic modernity and Western affluence, duplicity, and greed.

\section{eBay: The Final Deceptive Entanglement}

Eastern Iatmul never viewed tourism as "real development." But as long as human visitors traveled the river, there was little need to summon 
deceased kin dressed as otherworldly tourists in a ship packed with commodities. Tourism enabled Eastern Iatmul to feel some semblance of connection to the wider world and the promises of modernity. Visitors, too, offered validation. But with the final voyage of the Melanesian Discoverer, the village suddenly lost its mooring amid the capitalist flows of globalization-cut loose, to draw on a local idiom, like an untethered canoe, floating downriver.

In 20I0, Eastern Iatmul also grappled with a broad degradation in "basic services" compounded by the aftermath of a devastating flood and the lack of assistance by the provincial and national governments. In this terrible milieu, is it any wonder that Eastern Iatmul view the exodus of tourists through a lens of near-biblical proportions that entangles material well-being with Jesus, ghosts, the Internet, missionaries, Australia, America, Asians, and myself? For pathos and woe, Cannibal Tours has nothing on this tragedy.

In March 20I2, an eBay seller offered an "Antique Papua New Guinea Sepik River Mask made by Simon Bangu Tambunum Village East Sepik Province" for us $\$ 279.00$. The seller noted that a similar mask was once offered for US\$1,700.00. In fact, on 23 April 2012 eBay hosted thirty Iatmul objects ranging in price from Us $\$ 2,959.99$ for a "Rare Roof Finial Palembie [village] Iatmul Sepik Carved Totem Female Statue" to us \$4 I.99 for a "Decorative Canvas Print Iatmul Rattan Gable Mask." That month, when I searched eBay for "Sepik Ethnographic," I found 284 objects, many stating "Buy It Now" for over Us\$I,000.00. I doubt any of these pieces will fetch these exorbitant sums. To my eye, none of the objects appear "rare," "old," "ancient," or "kept in the men's spirit house." Far different was Lot 207 online at Sotheby's for an auction in May 2012. This male figure was estimated to fetch us $\$ 60,000.00-90,000.00$.

How would Eastern Iatmul react to online auctions of their old and touristic objects? I happen to know Simon Bangu. He sketched a design I printed on two-dozen T-shirts and brought to the Sepik in 2008 (see Silverman 200Ib). What would Simon say about the use of his name as an authenticating imprimatur on one of his wood carvings now selling for far more than he received at the initial transaction? Would he feel pride? Bemusement? Or would Simon and other villagers see these auctions as yet another example of how Europeans benefit at Eastern Iatmul expense? Indeed, these objects confirm cargoistic notions of white people pilfering and reselling goods that should rightfully benefit local people. And surely my friend Simon Marmus Gamboromiawan would see eBay as verifica- 
tion that the "Internet," however diffusely he understands it, holds promise for opening a "road" to modernity—if only Eastern Iatmul could learn the code to cyberspace.

By locating cargo in the netherworld, Eastern Iatmul today seem to place material success ever further out of reach, even as they believe these goods to float, almost literally, ever closer. At the same time, this millenarianism accurately represents the likelihood that local people will grasp the riches promised by modernity. Or perhaps their recent cargoism expresses the local recognition that nothing in the world as they know it could possibly explain their plight in the post-touristic Sepik.

FIELDWORK WAS GRACIOUSLY SUPPORTED in 1988-I990 by the Fulbright Foundation, the Institute for Intercultural Studies, and the Graduate School and Department of Anthropology at the University of Minnesota; in 1994 by the Wenner-Gren Foundation for Anthropological Research and DePauw University; in 2008 by Wheelock College; and in 2010 by Wheelock College and the Institute for Money, Technology, and Financial Inclusions at the University of California at Irvine. The comments of three anonymous readers were enormously helpful. My indebtedness to the people of Tambunum remains profound, and I apologize for any misrepresentations.

\section{Notes}

I Recent works on Melanesian tourism include Senft I999; Halvaksz 2006; Muke, Denham, and Genorupa 2007; West 2008; Martin 2010; Shaw 2010; Wearing, Wearing, and McDonald 20I0; and Stasch $20 \mathrm{II}$.

2 See http://www.mtsdiscoverer.auz.it/

3 An anonymous reader mentioned the presence of tourists in David Lan's I979 play about the Yali Movement, Sergeant Ola.

\section{References}

Adams, Kathleen 2006 Art as Politics: Re-crafting Identities, Tourism, and Power in Tana Toraja, Indonesia. Honolulu: University of Hawai'i Press.

Adams, Kathleen, and Peter Sanchez

2008 Indonesian Souvenirs as Micro-Monuments to Modernity: Hybridization, Deterritorialization and Commoditization. In Tourism in Southeast Asia: Challenges and New Directions, edited by Michael 
Hitchcock, Victor T King, and Michael Parnwell, 69-82. Honolulu: University of Hawai'i Press.

Akin, David, and Joel Robbins, editors

I999 Money and Modernity: State and Local Currencies in Melanesia.

Association for Social Anthropology in Oceania Monograph I7.

Pittsburgh: University of Pittsburgh Press.

Bashkow, Ira

2006 The Meaning of Whitemen: Race and Modernity in the Orokaiva

Cultural World. Chicago: University of Chicago Press.

Bateson, Gregory

I936 Naven: A Survey of the Problems Suggested by a Composite Picture of the Culture of a New Guinea Tribe Drawn from Three Points of View. Cambridge, uk: Cambridge University Press.

Bell, Joshua A

2006 Marijuana, Guns, Crocodiles and Submarines: Economies of Desire in the Purari Delta. Oceania 76 (3): 220-234.

Benediktsson, Karl

2006 Harvesting Development: The Construction of Fresh Food Markets in Papua New Guinea. Ann Arbor: The University of Michigan Press.

Burke, Timothy

I996 Lifebuoy Men, Lux Women: Commodification, Consumption, and Cleanliness in Modern Zimbabwe. Durham, NC: Duke University Press.

Causey, Andrew

2003 Hard Bargaining in Sumatra: Western Travelers and Toba Bataks in the Marketplace of Souvenirs. Honolulu: University of Hawai'i Press.

Clark, Jeffrey

I989 The Incredible Shrinking Men: Male Ideology and Development in a Southern Highland Society. Canberra Anthropology I 2 (I/2): I 20-I 43 .

Coiffier, Christian

I992 Rituels et identité culturelle iatmul (Vallée du Sépik - Papouasie Nouvelle-Guinée). Bulletin de l'Ecole française d'Extrême-Orient 79 (2): I $3 \mathrm{I}-\mathrm{I} 48$.

Curry, George

I999 Markets, Social Embeddedness and Precapitalist Societies: The Case of Village Tradestores in Papua New Guinea. Geoforum 30:285298.

2005 Doing “Business” in Papua New Guinea: The Social Embeddedness 
of Small Business Enterprises. Journal of Small Business and Entrepreneurship I 8 (2): 23 I-236.

Dougoud, Roberta Colombo

2005 "Ol i kam long hul bilong Wotñana" (They Come from the Hole of Wotñana): How a Papua New Guinean Artefact Became Traditional. In Tradition and Agency: Tracing Cultural Continuity and Invention, edited by Ton Otto and Poul Pedersen, 235-266. Aarhus, DK: Aarhus University Press.

Eriksen, Annelin

forthcoming A Cursed Past and a Prosperous Future in Vanuatu: A Comparison of Different Conceptions of Self and Healing. In Future Selves in the Pacific: Projects, Politics and Interests, edited by Will Rollason. Oxford: Berghahn.

Ferguson, James

2002 Global Disconnect: Abjection and the Aftermath of Modernism. In The Anthropology of Globalization: A Reader, edited by Jonathan X Inda and Renato Rosaldo, I36-I 53. Malden, MA: Blackwell Publishing.

Foster, Robert J

2002 Materializing the Nation: Commodities, Consumption, and the Media in Papua New Guinea. Bloomington: Indiana University Press.

Gesch, Patrick F

I985 Initiative and Initiation: A Cargo Cult-type Movement in the Sepik against Its Background in Traditional Village Religion. St Augustin, DE: Anthropos-Institut.

Gewertz, Deborah B

I983 Sepik River Society: A Historical Ethnography of the Chambri and Their Neighbors. New Haven: Yale University Press.

Gewertz, Deborah B, and Frederick K Errington

I99I Twisted Histories, Altered Contexts: Representing the Chambri in a World System. Cambridge, UK: Cambridge University Press.

I999 Emerging Class in Papua New Guinea: The Telling of Difference. Cambridge, uk: Cambridge University Press.

Halvaksz, Jamon A

2006 Becoming "Local Tourists": Travel, Landscapes and Identity in Papua New Guinea. Tourist Studies 6 (2): 99-II7.

2008 Whose Mine Closure? Appearances, Temporality and Mineral Extraction along the Upper Bulolo River, Papua New Guinea. Journal of the Royal Anthropological Institute I4:2 I-37. 
Harding, Thomas G

I967 A History of Cargoism in Sio, North-East New Guinea. Oceania 38 (I): I-23.

Hawksley, Charles

2006 Papua New Guinea at Thirty: Late Decolonisation and the Political Economy of Nation-Building. Third World Quarterly 27 (I): I6II73.

Hermann, Elfriede

I992 The Yali Movement in Retrospect: Rewriting History, Redefining “Cargo Cult." Oceania 63 (I): 55-7I.

Hriehwazi, Yehiura

20I I Mr Thinker. Post-Courier Online, 7 April. http://www.postcourier .com.pg/201 I0407/headlines.htm [accessed 3 January 20I3]

ICCCPNG and PNGTPA, Independent Consumer and Competition Commission PNG and Tourism Promotion Authority

2006 Papua New Guinea Tourism Sector Review and Master Plan (200720I7): Growing PNG Tourism as a Sustainable Industry; Final Report, 20 September. http://www.iccc.gov.pg/docs/Tourism\% 20 Sector\% 20 Review\% 20and\% 20Masterplan\% 20_Final\% 20Report\% 20 I90906.pdf [accessed 3 January 2013]

Jebens, Holger

2010 After the Cult: Perceptions of Other and Self in West New Britain (Papua New Guinea). New York: Berghahn.

Kirsch, Stuart

2006 Reverse Anthropology: Indigenous Analysis of Social and Environmental Relations in New Guinea. Stanford: Stanford University Press.

Knauft, Bruce M

I978 Cargo Cults and Relational Separation. Behavior Science Research I $3: 185-240$.

2002 Exchanging the Past: A Rainforest World of Before and After. Chicago: University of Chicago Press.

Kulick, Don

I992 Language Shift and Cultural Reproduction: Socialization, Self, and Syncretism in a Papua New Guinean Village. Cambridge, uk: Cambridge University Press.

Lattas, Andrew

2000 Telephones, Cameras and Technology in West New Britain Cargo

Leavitt, Stephen

Cults. Oceania $70(4):$ 325-344.

I995 Seeking Gifts from the Dead: Long-term Mourning in a Bumbita Arapesh Cargo Narrative. Ethos 23 (4): 453-473. 
2000 The Apotheosis of White Men? A Reexamination of Beliefs about

Lindstrom, Lamont Europeans as Ancestral Spirits. Oceania 70 (4): 304-323.

2000 Cargo Cult Horror. Oceania 70 (4): 294-303.

Lipset, David

2006 Tobacco, Good and Bad: Prosaics of Marijuana in a Sepik Society. Oceania 76 (3): 245-257.

2009 A Melanesian Pygmalion: Masculine Creativity and Symbolic Castration in a Postcolonial Backwater. Ethos 37 (I): 50-77.

20I I The Tides: Masculinity and Climate Change in Coastal Papua New Guinea. Journal of the Royal Anthropological Institute I 7:20-43.

Maher, Robert Francis

I96I New Men of Papua: A Study in Culture Change. Madison: University of Wisconsin Press.

Martin, Keir

2007 Your Own Buai You Must Buy: The Ideology of Possessive Individualism in Papua New Guinea. Anthropological Forum 17 (3): 285298.

2010 Living Past: Contested Tourism Authenticities. Annals of Tourism Research 37 (2): 537-554.

McGregor, Andrew, and R Michael Bourke

2009 The Broader Economy. In Food and Agriculture in Papua New Guinea, edited by R Michael Bourke and Tracy Harwood, 27 I-282. Canberra: ANu ePress.

Muke, John, Tim Denham, and Vagi Genorupa

2007 Nominating and Managing a World Heritage Site in the Highlands

Nalu, Malum of Papua New Guinea. World Archaeology 39 (3): 324-338.

2010 The Day the Tourism Died in Papua New Guinea. Blog, I9 July. http://malumnalu.blogspot.com/2010/o7/day-tourism-died-in-papua -new-guinea.html [accessed 3 January 2013]

Newton, Douglas

I997 Materials for an Iatmul Chronicle, Middle Sepik River (East Sepik

Ogan, Eugene Province, Papua New Guinea. Baessler Archiv (ns) 45:367-385.

I974 Cargoism and Politics in Bougainville I962-I974. Journal of Pacific History 9:I I 7-I 29.

O’Rourke, Dennis, director and cinematographer

I988 Cannibal Tours. Documentary film. Australia: Direct Cinema Limited.

Otto, Ton

2009 What Happened to Cargo Cults? Material Religions in Melanesia and the West. Social Analysis 53 (I): 82-102. 
Otto, Ton, and Robert J Verloop

I996 The Asaro Mudmen: Local Property, Public Culture? The Contemporary Pacific 8:349-386.

Robbins, Joel

2004 Becoming Sinners: Christianity and Moral Torment in a Papua New Guinea Society. Berkeley: University of California Press.

Roscoe, Paul B

2004 The Evolution of Revitalization of Movements among the Yangoru Boiken, Papua New Guinea. In Reassessing Revitalization Movements: Perspectives from North America and the Pacific Islands, edited by Michael E Harkin, I62-I82. Lincoln: University of Nebraska Press.

Scott, James C

I985 Weapons of the Weak: Everyday Forms of Peasant Resistance. New Haven: Yale University Press.

Senft, Gunter

I999 The Presentation of Self in Touristic Encounters: A Case Study from the Trobriand Islands. Anthropos 94:2 I-33.

Shaw, Wendy S

20I0 Serendipitous Coffee Experiences in Papua New Guinea. In Coffee Culture, Destinations and Tourism, edited by Lee Jolliffe, I34-I 57. Leeds: Short Run Press.

Silverman, Eric K

200га Art, Tourism and the Crafting of Identity in the Sepik River (Papua New Guinea). In Unpacking Culture: Art and Commodity in Colonial and Postcolonial Worlds, edited by Ruth B Phillips and Christopher B Steiner, 5 I-66. Berkeley: University of California Press.

200Ib From Totemic Space to Cyberspace: Transformations in Sepik River and Aboriginal Australian Myth, Knowledge and Art. In Emplaced Myth: Space, Narrative and Knowledge in Aboriginal Australia and Papua New Guinea Societies, edited by Alan Rumsey and James F. Weiner, I 89-2 I4. Honolulu: University of Hawai'i Press.

200Ic Masculinity, Motherhood, and Mockery: Psychoanalyzing Culture and the Iatmul Naven Rite in New Guinea. Ann Arbor: The University of Michigan Press.

2003 High Art as Tourist Art, Tourist Art as High Art: Comparing the New Guinea Sculpture Garden at Stanford University and Sepik River Tourist Art. International Journal of Anthropology I8:2 I9230. (Reprinted in Exploring World Art, edited by Eric Venbrux, Pamela Sheffield Rosi, and Robert L Welsch, 27 I-I 84. Long Grove, IL: Waveland Press, 2006.)

2004 Cannibalizing, Commodifying, and Creating Culture: Power and 
Creativity in Sepik River Tourism. In Globalization and Culture Change in the Pacific Islands, edited by Victoria S Lockwood, 339357. Upper Saddle River, NJ: Pearson/Prentice-Hall.

Smith, Michael French

I994 Hard Times on Kairiru Island: Poverty, Development, and Morality in a Papua New Guinea Village. Honolulu: University of Hawai'i Press.

Stasch, Rupert

20I I Textual Iconicity and the Primitivist Cosmos: Chronotopes of Desire in Travel Writing about Korowai of West Papua. Journal of Linguistic Anthropology 2I (I): I-2I.

Sykes, Karen

200I Paying a School Fee is a Father's Duty: Critical Citizenship in Central

Tuzin, Donald F

New Ireland. American Ethnologist 28 (I): 5-3 I.

I997 The Cassowary's Revenge: The Life and Death of Masculinity in a New Guinea Society. Berkeley: University of California Press.

Wearing, Stephen Leslie, Michael Wearing, and Matthew McDonald

2010 Understanding Local Power and Interactional Processes in Sustainable Tourism: Exploring Village-Tour Operator Relations on the Kokoda Track, Papua New Guinea. Journal of Sustainable Tourism I 8 (I): 6I-76.

Wesley-Smith, Terence

2007 The Limits of Self-Determination in Oceania. Social and Economic Studies 56 (I/2): I 82-208.

West, Paige

2008 Tourism as Science and Science as Tourism: Environment, Society, Self, and Other in Papua New Guinea. Current Anthropology 49 (4): $597-626$.

Zimmer-Tamakoshi, Laura

I997 Last Big Man: Development and Men's Discontents in the Papua New Guinea Highlands. Oceania 68 (2): I07-I22.

\section{Abstract}

This article challenges the ethical allegory of the widely hailed film Cannibal Tours, drawing on two decades of ethnographic research in the Sepik region of Papua New Guinea, most recently in 2010. First, I sketch the contemporary plight of a middle Sepik, Iatmul-speaking community that yearns for a "road" to modernity and tourism but increasingly sees itself as "going backwards." Second, I argue that tourism allows middle Sepik inhabitants to express artistically subtle 
messages about contemporary gender, identity, and sociality in the Melanesian postcolony. Third, I demonstrate what happens when the tourists go home. And almost all of them have done so, especially after the sale of the tourist ship, the Melanesian Discoverer, in 2006. Tragically, the recent decline in tourism corresponds to a dramatic degradation of "basic services" offered by provincial and national authorities, and a devastating flood during the 2009-2010 rainy season. Facing all this, Iatmul feel increasingly disenfranchised, despondent, and desperate to attract new tourists and to discover, after a century of unfilled commodity desires, the source of material plenitude locally associated with modernity. Toward this aim, villagers now speak about something I never expected to hear in this once prosperous community: narratives about deceased kin, voyaging back to the village like ghostly tourists on a numinous ship, striving to bring local people wealth and commodities, only to be barred by Europeans. What happens after Cannibal Tours? The ideology of a cargo cult.

KEYWORDs: tourism, development, Sepik River, Papua New Guinea, Cannibal Tours, art, cargo cult 